\title{
Nonsecretory Multiple Myeloma in a Seropositive Hepatitis B Patient with Thrombocytosis: A Case Report
}

\author{
Muhammad Ali Fayyaz \\ Medical Officer, Quaid e Azam Medical College, Bahawalpur, Pakistan
}

\begin{abstract}
A B STRACT
Non-secretory Multiple Myeloma is a rare variant of multiple myeloma with similar clinical and radiological findings. It is characterized by the absence/lack of monoclonal $\mathrm{M}$ proteins in the serum and/or urine. An early diagnosis can help in alleviating its adverse outcomes. We report a case of a 56-year-old female presenting with generalized body weakness and swelling, pain in right lower chest and anorexia. The patient was a known case of hepatitis B, treated a month ago. There was an incidental finding of thrombocytosis. Serum biochemistry and protein electrophoresis showed no findings in favor of Multiple Myeloma. Bence Jones proteins were negative in the urine. X-ray revealed few lytic lesions on calvaria of the skull. Bone marrow biopsy helped in diagnosing the patient as a case of non-secretory type of multiple myeloma highlighting the important role of this modality in saving the life of a patient through early diagnosis.
\end{abstract}

Key Words: Hepatitis B, Lytic bone lesions, Multiple Myeloma, Thrombocytosis.

$\begin{array}{ll}\text { Correspondence: } & \text { Article info: } \\ \text { Muhammad Ali Fayyaz } & \text { Received: November 27, 2020 } \\ \text { Email: mafayyazbonamana1@gmail.com } & \text { Accepted: June 25, 2021 }\end{array}$

Cite this case Report: Fayyaz M A. Nonsecretory Multiple Myeloma in a Seropositive Hepatitis B Funding Source: Nil patient with Thrombocytosis: A Case Report. J Islamabad Med Dental Coll. 2021; 10(2): 120-124. C Conflict of Interest: Nil Doi: 10.35787/jimdc.v10i2.632

\section{Introduction}

Multiple Myeloma (MM) is monoclonal gammopathy, mainly diagnosed by the detection of monoclonal immunoglobulins in the serum and urine. MM is a neoplasm of B-lymphocytes lineage, characterized by extravagant multiplication of the aberrant plasma cells, known as myeloma cells, secreting monoclonal paraprotein (M protein) which may be a complete immunoglobulin or one of its light or heavy chain. ${ }^{1}$ Multiple Myeloma is more frequent in males than females. Body Mass Index (BMI) may play a role in developing $\mathrm{MM}^{2}{ }^{2}$ Pesticides, insecticides or chemicals containing carcinogens may be potential causes of MM. ${ }^{3}$
Non-secretory Multiple Myeloma (NSMM) is a rare variant of $\mathrm{MM}$, in which immunoglobulins are neither found nor detected in the serum or urine. It is also a plasma cell cancer with the same clinical and radiological manifestations as that of classical MM, but plasma cells are unable to secrete immunoglobulins. ${ }^{4}$ Moreover, unlike the classical disease, NSMM is also characterized by the absence of end-organ damage i.e., renal, hematological or other systemic complications. Such cases are rare and challenging to diagnose.

CRAB criteria indicate the presence of end-organ damage in MM. It is characterized by HyperCalcemia with calcium level more than $11.5 \mathrm{mg} / \mathrm{dl}$ due to 
increased osteoclastic activity, Renal insufficiency with creatinine level greater than $2 \mathrm{mg} / \mathrm{dL}$, Anemia with hemoglobin level less than $10 \mathrm{~g} / \mathrm{dL}$, and Bony lesions ('punched out' or 'soap bubbles' lesions) that results in bone pain and fractures. ${ }^{1,3}$ Pancytopenia, hyperviscosity syndrome, amyloidosis, recurrent infections due to decreased immunity, bone collapse and Bence Jones (BJ) proteinuria are other associated signs of MM.

Hematological tumors along with $\mathrm{MM}$ are usually associated with decreased platelet count (thrombocytopenia). Incidence of increased platelet count (thrombocytosis) is infrequent in cases of classic Multiple Myeloma. ${ }^{5}$

Diagnosis of Multiple Myeloma is usually confirmed after a detailed medical history, physical examination, complete blood count, ESR, serum biochemistry, serum and urine electrophoresis for immunoglobulins and BJ proteins evaluation in urine. Bone lesions can be detected by X-rays, MRI, PET and CT scan. ${ }^{6}$ The percentage of plasma cells $(>10 \%)$ in bone marrow biopsy is considered to be a diagnostic method for Multiple Myeloma or its variants. However, there are some discrepancies between the percentage of plasma cells in bone marrow aspiration and bone marrow biopsy for diagnosing the disease. ${ }^{7}$

Hepatitis B infection is a worldwide public health problem, and very common in Pakistan. Association of hepatitis $B$ virus with hematological malignancies has been stated earlier; however, there is a weak association between hepatitis $\mathrm{B}$ and $\mathrm{MM}{ }^{8}$

\section{Case Report}

A 56-year-old housewife presented to the Medical OPD of Bahawal Victoria Hospital, Bahawalpur Pakistan with generalized weakness (2 months), generalized body swelling (1.5 months), pain in right lower chest (1 month) and anorexia (1 week). On physical examination, she was conscious, active and cooperative. Lymph nodes were not palpable. Mild pallor and no signs of cyanosis were found. Heart rate was regular at $96 \mathrm{bpm}$, blood pressure was $110 / 75 \mathrm{mmHg}$, respiratory rate 32 breaths per minute, temperature was $99.4^{\circ} \mathrm{F}$, oxygen saturation was $99 \%$. Abdomen was soft but mild tenderness was present in the right hypochondrium. Crepitations were audible in the right chest.

She was admitted and treated first with intramuscular analgesics (diclofenac, tramadol and pregabalin), but no improvement was recorded. Antibiotics and Proton pump inhibitors were also given to the patient but her condition did not improve.

The patient had been diagnosed as a case of hepatitis $B$ and completed treatment one month ago. Hepatitis B surface antigen ( $\mathrm{HBsAg}$ ) was still positive and HBV DNA was detected by Real time PCR (1112 IU/L), while the RA factor was negative.

Bence Jones (BJ) proteins in the urine and serum were negative (Table I; Figure 1).

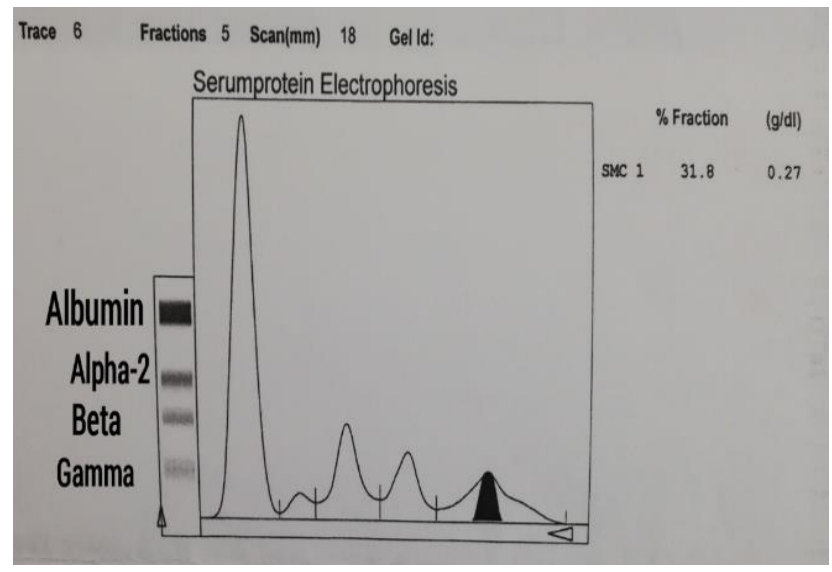

Figure 1: Serum protein Electrophoresis. Normal peaks of Alpha 1, Alpha 2, Beta and Gamma globulins without any $M$ spike

Multiple lytic lesions were observed on x-ray skull (Figure 2), while bone scan was normal. Bone marrow biopsy revealed $85-90 \%$ plasma cell infiltrate (Figure 3). 


\begin{tabular}{|c|c|c|}
\hline \multicolumn{3}{|c|}{$\begin{array}{c}\text { Table I: Hematology, biochemistry and serum } \\
\text { electrophoresis reports }\end{array}$} \\
\hline \multicolumn{3}{|c|}{ COMPLETE BLOOD COUNT } \\
\hline & Results & Normal Range \\
\hline WBC's & 13700 / ul & $4000-11000 / \mathrm{ul}$ \\
\hline Lymphocytes & $37.9 \%$ & $20-45 \%$ \\
\hline Neutrophils & $77 \%$ & $40-75 \%$ \\
\hline $\mathrm{RBC}^{\prime} \mathrm{s}$ & $3500000 / \mathrm{ul}$ & $\begin{array}{l}3790000-5780000 / \\
\text { ul }\end{array}$ \\
\hline Hemoglobin & $10.5 \mathrm{~g} / \mathrm{dL}$ & $11-15 / d L$ \\
\hline $\mathrm{MCH}$ & $28.8 \mathrm{pg}$ & $27.5-32.4 \mathrm{pg}$ \\
\hline MCV & $88 \mathrm{fL}$ & $84-98 \mathrm{fL}$ \\
\hline $\mathrm{MCHC}$ & $34 \mathrm{~g} / \mathrm{dL}$ & $31.7-34.2 \mathrm{dL}$ \\
\hline Platelets & 475000 / ul & $150000-400000$ / ul \\
\hline Hematocrit & $32.1 \%$ & $34-53 \%$ \\
\hline ESR & $\begin{array}{l}40 \mathrm{~mm} / 1 \mathrm{st} \\
\text { hour }\end{array}$ & $0-20 \mathrm{~mm} / 1 \mathrm{st}$ hour \\
\hline \multicolumn{3}{|c|}{ BLOOD BIOCHEMISTRY } \\
\hline & Results & Normal Range \\
\hline $\begin{array}{l}\text { Glucose } \\
\text { (Random) }\end{array}$ & $80 \mathrm{mg} / \mathrm{dl}$ & $70-140 \mathrm{mg} / \mathrm{dl}$ \\
\hline Urea & $42 \mathrm{mg} / \mathrm{dl}$ & $10-50 \mathrm{mg} / \mathrm{dl}$ \\
\hline Creatinine & $1.7 \mathrm{mg} / \mathrm{dl}$ & $0.5-0.9 \mathrm{mg} / \mathrm{dl}$ \\
\hline Bilirubin & $0.5 \mathrm{mg} / \mathrm{dl}$ & $<1 \mathrm{mg} / \mathrm{dl}$ \\
\hline ALT & $23 \mathrm{U} / \mathrm{L}$ & $<31 \mathrm{U} / \mathrm{L}$ \\
\hline $\begin{array}{l}\text { Alkaline } \\
\text { Phosphatase }\end{array}$ & $125 \mathrm{U} / \mathrm{L}$ & $<120 \mathrm{U} / \mathrm{L}$ \\
\hline Sodium & $137 \mathrm{mEq} / \mathrm{L}$ & $135-155 \mathrm{mEq} / \mathrm{L}$ \\
\hline Potassium & $4.0 \mathrm{mEq} / \mathrm{L}$ & $3.5-5.5 \mathrm{mEq} / \mathrm{L}$ \\
\hline CPK & $129 \mathrm{U} / \mathrm{L}$ & $24-170 \mathrm{U} / \mathrm{L}$ \\
\hline Albumin & $3.2 \mathrm{~g} / \mathrm{dl}$ & $3.8-4.4 \mathrm{~g} / \mathrm{dl}$ \\
\hline Calcium & $9.4 \mathrm{mg} / \mathrm{dl}$ & $8.1-10.4 \mathrm{mg} / \mathrm{dl}$ \\
\hline \multicolumn{3}{|c|}{ SERUM PROTEIN ELECTROPHORESIS } \\
\hline & Results & Normal Range \\
\hline Albumin & $2.90 \mathrm{~g} / \mathrm{dl}$ & $3.20-5.50 \mathrm{~g} / \mathrm{dl}$ \\
\hline Alpha 1 & $0.20 \mathrm{~g} / \mathrm{dl}$ & $0.10-0.40 \mathrm{~g} / \mathrm{dl}$ \\
\hline Alpha 2 & $0.90 \mathrm{~g} / \mathrm{dl}$ & $0.40-1.20 \mathrm{~g} / \mathrm{dl}$ \\
\hline Beta & $0.65 \mathrm{~g} / \mathrm{dl}$ & $0.50-1.10 \mathrm{~g} / \mathrm{dl}$ \\
\hline Gamma & $0.85 \mathrm{~g} / \mathrm{dl}$ & $0.50-1.60 \mathrm{~g} / \mathrm{dl}$ \\
\hline A/G Ratio & 1.12 & \\
\hline Total Protein & $5.50 \mathrm{~g} / \mathrm{dl}$ & $6.40-8.30 \mathrm{~g} / \mathrm{dl}$ \\
\hline
\end{tabular}

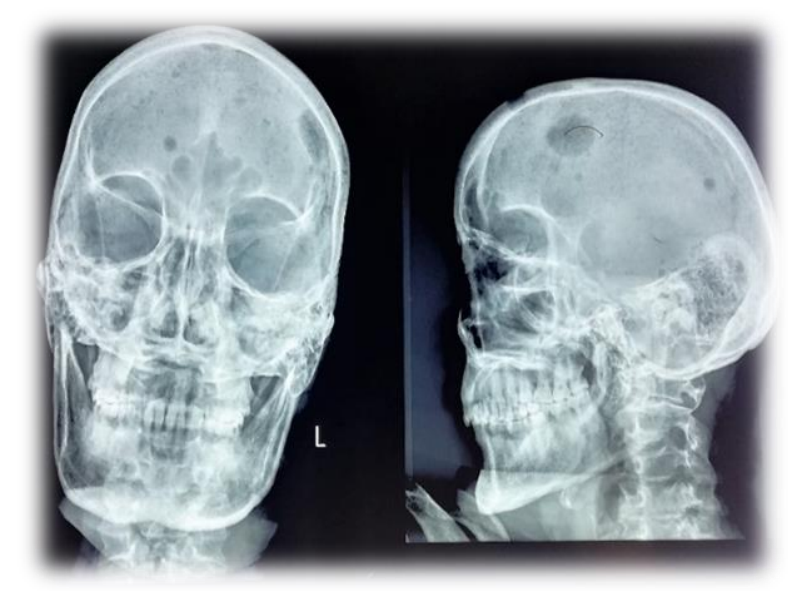

Figure 2: X-Ray Skull PA and Lateral view. Lytic ('punched out') lesions resembling 'soap bubbles' can easily be observed in both views.

\section{Discussion}

Multiple myeloma accounts for approximately 10$15 \%$ of all hematological cancers and one to two per cent of all neoplasms. ${ }^{1}$ Different variants of multiple myeloma are emerging with atypical features clinically, radiologically and pathologically, making diagnosis challenging for physicians. Bone marrow biopsy and Flow cytometry (CMF) can be useful tools in identifying different types of multiple myeloma. ${ }^{9}$ Multiple myelomas is a manifestation of plasma cell neoplasm, classically presenting as multiple lytic (punched out) bony lesions accompanied by an increase in the number of bone marrow plasma cells (>10\%). Immunoglobulin or fragments of immunoglobulins are produced by the neoplastic plasma cells leading to a monoclonal band in serum protein electrophoresis (SPE) and/or BJ proteinuria. Almost $1-5 \%$ of all cases may not show the band on SPE and BJ proteins in urine which are called "NonSecretory Multiple Myeloma (NSMM)" or "Nonproductive Multiple Myeloma". Lack of M-spike in SPE, BJ proteinuria and normal serum calcium levels are uncommon features in classical Multiple Myeloma. So, our patient having none of the classical features, was diagnosed as NonSecretory/Non-Productive Multiple myeloma. 


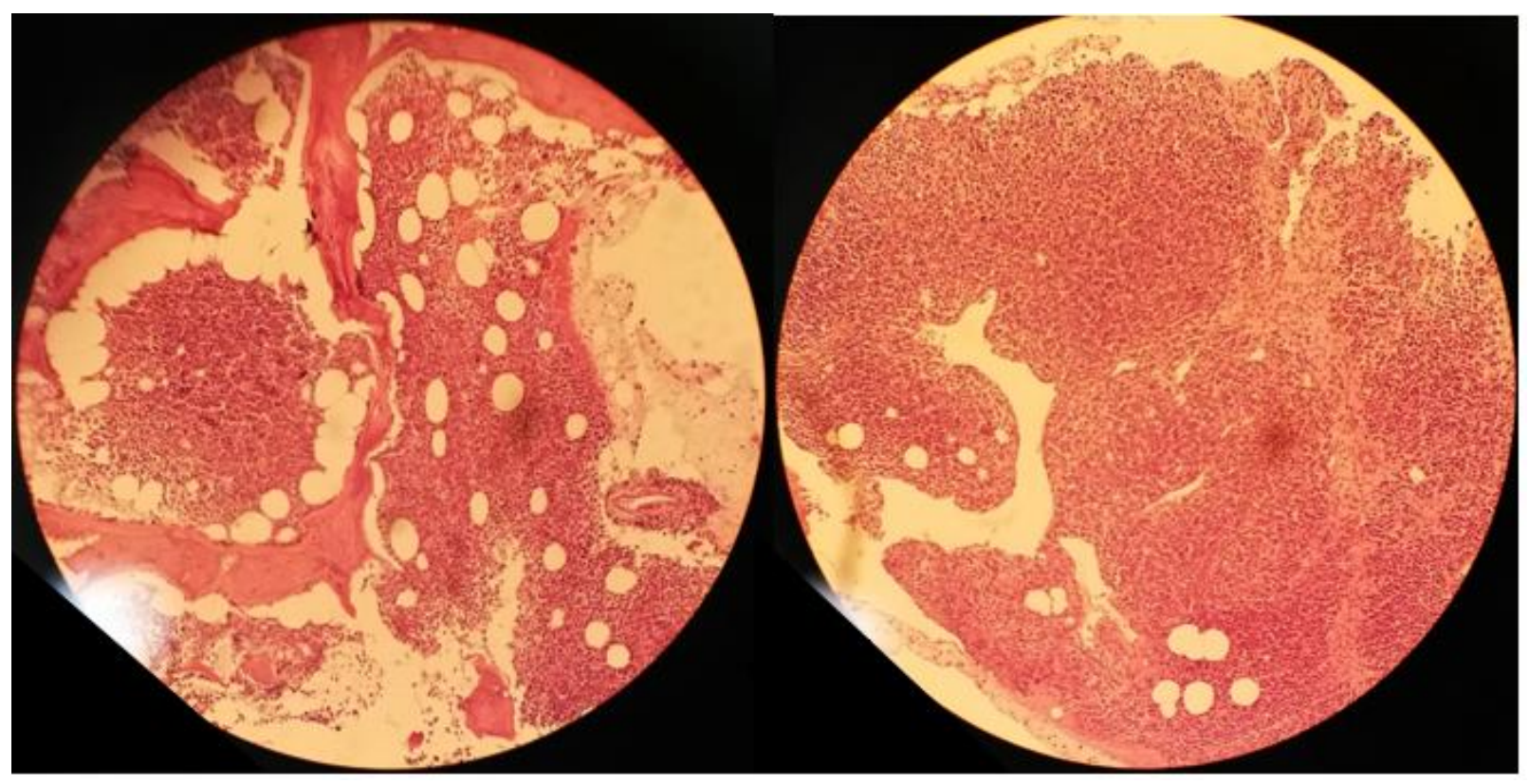

Figure 3: Bone marrow trephine biopsy showing abundant plasma cells infiltrate

The NSMM is further divided into two types; one in which the cancerous plasma cells produce immunoglobulins but do not secrete it and the true non- secretors, which do not produce immunoglobulins at all. ${ }^{10}$

Hepatitis B virus (HBV) is a DNA virus with an oncogenic potential targeting different cells in blood, spleen, lymph nodes, thymus and bone marrow. ${ }^{11}$ Hepatitis $B$ infection may have some association with the development of $\mathrm{MM}^{12,13}$ Deletion of $8 p$ chromosome in patients of MM was observed in 680 patients of the National Center for Tumor Diseases Heidelberg, Germany in approximately $40 \%$ HBV-positive patients compared with $20-30 \%$ HBV-negative patients. ${ }^{14}$ The prevalence of acute and chronic HBV infection in patients with $\mathrm{MM}$ was observed in $11.5 \%$ and $14.54 \%$, respectively. ${ }^{15}$

Thrombocytosis is an atypical feature in $\mathrm{MM}$ as these cases are characterized by myelosuppression. ${ }^{5}$ Our patient also had an incidental finding of thrombocytosis during routine workup. In a study involving 280 hospitalized patients with high platelet count, $82 \%$ (231 patients) had secondary thrombocytosis, $14 \% \quad$ (38 patients) had Myeloproliferative Disorders while only 4\% (11 patients) had thrombocytosis of unknown cause. ${ }^{16}$ Myeloma has been reported in cases of MPDs causing high platelet count. It can be paraneoplastic manifestation of plasma cell cancers. Different studies describe it as POEMS syndrome, in which thrombocytosis is a minor feature. ${ }^{17,18}$ Even some cases of MM having raised C-Reactive Protein (CRP) are reported with thrombocytosis. ${ }^{19}$ The exact mechanism is still unknown. Further study is still needed to identify the cause and mechanism behind thrombocytosis in multiple myeloma patients.

Multiple Myeloma is a slowly progressing disease. Therefore, survival time is about 4 to 6 years. There is no cure for multiple myeloma, but the period of survival can be enhanced by treatment with chemotherapy.

\section{Informed Consent}

Verbal informed consent was obtained from the patient for her anonymized information to be published in this article. 


\section{Conclusion}

To the best of our knowledge, this is the first reported case of NSMM in association with Hepatitis $B$ and thrombocytosis. A bone marrow biopsy/trephine biopsy should be performed for any suspected case of $\mathrm{MM}$ or its variants. This will not only help in an early diagnosis but also save patient from life-threatening late-stage complications. A high index of suspicion should be kept in mind to avoid delay in diagnosing the disease.

\section{References}

1. Puri A, Wadhwa H, Singh N. Nonsecretory Multiple Myeloma with HCV Infection: A Rare Case Entity. Iran J Pathol. 2018; 13(2): 281-4. Doi: 10.30699/ijp.13.2.281.

2. Yao J, Lv D, Chen W. Multiple Myeloma, Misdiagnosed as Somatic Symptom Disorder: A Case Report. Front Psychiatry. 2018; 9: 557. Doi: 10.3389/fpsyt.2018.00557.

3. Packard E, Shahid Z, Groff A, Patel R, Jain R. Multiple Myeloma in an Agricultural Worker Exposed to Pesticides. Cureus. 2019; 11(5): e4762. Doi: $10.7759 /$ cureus. 4762.

4. Bensalah $M$, Lamrabat $S$, Lyagoubi $A$, Aarab A, Bouayadi O, Seddik R. A rare case of Nonsecretory multiple myeloma: a case report and literature review. EJIFCC. 2019; 30(1): 88-94. PMID: 30881278.

5. Naeem A, Amar S, Mehta D, Malik MN. Thrombocytosis as an Initial Presentation of Plasma Cell Neoplasm: A Case Report. Cureus. 2019; 11(3): e4286. Doi: 10.7759/cureus.4286.

6. Palumbo A, Cerrato C. Diagnosis and therapy of multiple myeloma. Korean J Intern Med. 2013; 28(3): 263 -73. Doi: 10.3904/kjim.2013.28.3.263.

7. Lee N, Moon SY, Lee JH, Park HK, Kong SY, Bang SM, et al. Discrepancies between the percentage of plasma cells in bone marrow aspiration and BM biopsy: Impact on the revised IMWG diagnostic criteria of multiple myeloma. Blood Cancer J. 2017; 7(2): e530. Doi: 10.1038/bcj.2017.14.

8. Marcucci F, Mele A. Hepatitis viruses and nonHodgkin lymphoma: Epidemiology, mechanisms of tumorigenesis, and therapeutic opportunities. Blood. 2011; 117: 1792-8. Doi: 10.1182/blood-2010-06275818.
9. Olteanu H. Role of Flow Cytometry in the Diagnosis and Prognosis of Plasma Cell Myeloma. Surg Pathol Clin. 2016; 9(1): 101-16. Doi: 10.1016/j.path.2015.09.009.

10. Janicki P, Niemczyk S. Non-secretory multiple myeloma in a patient with chronic kidney disease. Pol Merkur Lekarski. 2020; 48(287): 344-5. PMID: 33130796.

11. Sinha $M$, Rao $C R$, Premalata $C S$, Shafiulla $M$, Lakshmaiah KC, Jacob LA, et al. Plasma Epstein-Barr virus and Hepatitis $B$ virus in non-Hodgkin lymphomas: Two lymphotropic, potentially oncogenic, latently occurring DNA viruses. Indian J Med Paediatr Oncol. 2016; 37: 146-51. Doi: 10.4103/0971-5851.190353.

12. Li Y, Bai O, Liu C, Du Z, Wang X, Wang G, et al. Association between hepatitis $B$ virus infection and risk of multiple myeloma: A systematic review and meta-analysis. Intern Med J. 2016; 46(3): 307-14. Doi: 10.1111/imj.12981.

13. Su TH, Liu CJ, Tseng TC, Chou SW, Liu CH, Yang HC, et al. Chronic hepatitis $B$ is associated with an increased risk of B-cell non-Hodgkin's lymphoma and multiple myeloma. Aliment Pharmacol Ther. 2019; 49(5): 58998. Doi: 10.1111/apt.15132.

14. Becker N, Byl A, Friedrich S, Jauch A, Schnitzler P, Egerer $G$, et al. Hepatitis $B$ virus infection is associated with deletion of chromosome $8 p$ in multiple myeloma. Eur J Haematol. 2013; 90: 279-85. Doi: 10.1111/ejh.12018.

15. Guo D, Xu P, Guan C, Xu Y, Yang Y, Xu J, et al. Hepatitis $B$ virus infection and $1 q 21$ amplification in multiple myeloma. Oncol Lett. 2019; 18(6): 6196-206. Doi: 10.3892/ol.2019.10926.

16. Buss DH, Cashell AW, O'Connor ML, Richards F, Case LD. Occurrence, etiology, and clinical significance of extreme thrombocytosis: a study of 280 cases. Am J Med. 1994; 96(3): 247-53. Doi: 10.1016/00029343(94)90150-3.

17. Dispenzieri A. POEMS Syndrome: 2019 Update on diagnosis, risk-stratification, and management. Am J Hematol. 2019; 94(7):812-827. Doi: 10.1002/ajh.25495.

18. Brown R, Ginsberg L. POEMS syndrome: clinical update. J Neurol. 2019; 266(1): 268-77. Doi: 10.1007/s00415-018-9110-6.

19. Král Z, Adam Z, Folber F, Moulis M, Tomíška M, Říhová L, et al. Systemic inflammatory response with high CRP values as the dominant symptom of multiple myeloma. Vnitr Lek. 2019; 65(1): 37-44. PMID: 30823836. 